\title{
SCIENTIFIC REPORTS

\section{OPEN The difference in dissipation of clomazone and metazachlor in soil under field and laboratory conditions and their uptake by plants}

\author{
Ewa Szpyrka ${ }^{*}$, Magdalena Słowik-Borowiec, Paulina Książek, Aneta Zwolak \& \\ Magdalena Podbielska
}

The study concerned dissipation of metazachlor and clomazone, herbicides widely used in rapeseed (Brassica napus L. subsp. napus) protection, applied to the clay soil under field and laboratory conditions. Furthermore, the uptake of these pesticide from soil by rapeseed plants was investigated under field conditions. An additional aim of this work was to modify the QuEChERS method for the determination of metazachlor and clomazone in the plant material. Analytical procedures for metazachlor and clomazone qualification and quantification in rapeseed plants and soil were developed, using gas chromatography with an micro electron capture detector (GC- $\mu E C D)$ and a mass detector (GC-MS/MS QqQ) as confirmation. Dissipation kinetics of herbicide residues in soil were described as first-order equations. The analytical performance was very satisfactory and confirmed that the methods meet the requirements of the European Commission. In the conducted field experiments it was found that dissipation of clomazone and metazachlor in clay soil follows first-order kinetics $\left(R^{2}\right.$ between 0.964 and 0.978 ), and half-lives were 9.5 days and 10.2 days for clomazone and metazachlor, respectively. Under laboratory conditions, dissipation of clomazone and metazachlor in soil also follows first-order kinetics ( $R^{2}$ between 0.937 and 0.938 ), and half-lives were 8.8 days and 5.7 days for clomazone and metazachlor, respectively. Residues of both herbicides in rape plants 22 days after application of herbicides were below the maximum residue levels for Brassica plants. Metazachlor and clomazone dissipate very fast in clay soil and their uptake by rape plants is very low.

The constantly growing demand for food requires the use of modern methods and technologies in agricultural production, including the use of plant protection products. As it is widely known, there is some evidence of advantageous effects of pesticides, such as an increase in the quantity and quality of crops $^{1}$, but, at the same time, the intensification of agriculture, including the use of these inherently toxic and highly persistent substances, can lead to environmental contamination, as well as consumer exposure that may be harmful to their health ${ }^{2-4}$. Because this problem raises serious social concerns, there are many governmental and international institutions that are responsible for establishing laws in this area. Codex Alimentarius ${ }^{5}$ or The Environmental Protection Agency ${ }^{6}$ establish maximum residue levels (MRLs) for pesticides in food, while in the European Union levels of pesticides are controlled in accordance with Regulation 396/2005 and Regulation 149/2008 ${ }^{8}$.

Indisputably, soil is an important agricultural resource able to produce, distribute and store matter and chemicals ${ }^{9}$. Soil may be exposed to both industrial and agricultural pollutions, including pesticides. These substances can be introduced into the soil in various ways, e.g. by direct application, accidental spillage, runoff from plants or by the inclusion of plant materials contaminated with pesticides. Once in the soil, pesticides can undergo one or more of the following processes: adsorption, leaching, degradation, evaporation, chemical and microbiological changes, or movement into the soil profile $\mathrm{e}^{10}$. The use of herbicides in crop fields allows limiting crop losses related to the competitiveness of weeds. Herbicides penetrate plants through their leaves and/or roots, and then they are 
distributed through a vascular system, disrupting plant's vital processes. The level of herbicide residues in plants depends on the ability to collect and metabolize the active substance by a given species. Weather conditions and a dose of a formulation also play an important role. Whereas, the degradation rate and/or the persistence of herbicides in the soil depend mainly on an active substance type, and on its physical and chemical properties, environmental conditions (soil type, temperature, humidity, $\mathrm{pH}$ ), and microorganisms (bacteria and fungi) ${ }^{11,12}$. Biodegradation of herbicides is faster in soils rich in microbes than in barren soils. For the complete inactivation of an herbicide, an interaction of various types of microorganisms is usually needed. Microbial degradation occurs fastest in surface soil layers, where the intensity of biological life is the highest. When intensive rainfall occurs after spraying, the active substance may move faster into the soil profile, where the prevailing conditions are less favorable for microflora and the microbial degradation is slower. The number and activity of soil microorganisms, and thus the rate of microbial degradation, is strongly influenced by soil temperature and humidity. Generally, as the temperature and humidity increase, the microbial degradation process accelerates. Periods of drought or low temperatures inhibit the growth of microorganisms, resulting in slowing down the decomposition of herbicides ${ }^{11}$.

Because herbicide treatments can be a source of pollution of plant products and of the soil environment, it is important to monitor these substances by multiresidue methods, facilitating an accurate and reliable measurement of their concentration levels, as well as a risk assessment ${ }^{10,13}$.

The literature describes many analytical methods available for the determination of pesticide residues in plant material and soil samples. To a large extent, these methods are based on traditional approaches: soxhlet extraction ${ }^{14-16}$, solid phase extraction ${ }^{17,18}$, pressurised liquid extraction ${ }^{19,20}$, matrix solid-phase dispersion ${ }^{21,22}$, solid-phase microextraction ${ }^{23,24}$, or dispersive liquid-liquid microextraction ${ }^{25}$. Currently, the QuEChERS procedure $^{26}$ is one of the most commonly used analytical methods for the determination of pesticides residues, and frequently this procedure is modified in terms of amounts and types of reagents, as well as available equipment ${ }^{27-30}$.

Information on the presence of pesticide residues in rapeseed plants or the dissipation of these substances is very limited, and only a few literature references concern the content of pesticides in oilseed rape or oil seeds ${ }^{31-34}$. For this reason, focusing our research on this area seems to be justified.

Herbicides containing clomazone and metazachlor as active substances are very popular and are recommended for simultaneous application in rapeseed crops. In the literature, the availability of information about the dissipation of these two herbicides in soil is limited, and the information about uptake of herbicide residues by rapeseed plants is scarce; therefore, these studies can be considered as a novel approach. The aim of the study was to analyze dissipation kinetics of clomazone and metazachlor under field and laboratory conditions, together with the uptake of residues of these herbicides by rapeseed plants. The additional aim was to develop and validate a method for the determination of metazachlor and clomazone in the plant material, as well as validation of a method for the analysis of these substances in the soil.

\section{Results}

Soil parameters. The soil was characterized by following parameters: soil type - clay; the granulometric composition: $2.37 \%$ of $1.0-0.1 \mathrm{~mm}$ fraction, $54.34 \%$ of $0.1-0.02 \mathrm{~mm}$ fraction, and $43.29 \%$ of $<0.02 \mathrm{~mm}$ fraction; soil pH 6.9; assimilable phosphorus $-20.1 \mathrm{mg} \mathrm{P}_{2} \mathrm{O}_{5} / 100 \mathrm{~g}$; total carbon - 1.02\%; organic carbon $-0.87 \%$; humus content $-1.5 \%$; total nitrogen $-0.12 \%$; phosphorus content $-850.20 \mathrm{mg} / \mathrm{kg}$, magnesium $-0.28 \%$, potassium $0.49 \%$, and calcium $-0.30 \%$.

Validation of a method for ananalysis of clomazone and metazachlor in soil. The average recovery in soil samples was determined for two fortification levels: $1 \mathrm{mg} / \mathrm{kg}$ for both substances, and $0.01 \mathrm{mg} /$ $\mathrm{kg}$ for clomazone, and $0.005 \mathrm{mg} / \mathrm{kg}$ for metazachlor. Precision was calculated from the recovery experiments and it was expressed as RSD at each spiking level. For all pesticides, a percentage range of mean recovery and RSD was acceptable and amounted to $88-112 \%$ and $7-13 \%$, respectively. The results obtained are presented in Supplementary Table S1.

Linearity of calibration curves in the "blank" matrix was studied over the concentration range between 0.01$2.88 \mu \mathrm{g} / \mathrm{mL}$ for clomazone and $0.005-2.12 \mu \mathrm{g} / \mathrm{mL}$ for metazachlor, by gas chromatography with a micro electron capture detector $(\mathrm{GC}-\mu \mathrm{ECD})$ analysis with satisfactory coefficients of determination $\left(\mathrm{R}^{2}\right) \geq 0.99$.

The limit of quantification (LOQ) for each pesticide were set at the lowest spiking concentrations $(0.01 \mathrm{mg} /$ $\mathrm{kg}$ for clomazone and $0.005 \mathrm{mg} / \mathrm{kg}$ for metazachlor), for which validation criteria, in the term of recovery and precision, were fulfilled ${ }^{35}$.

The expanded uncertainty was calculated as twice the value of the uncertainty $(\mathrm{k}=2$, confidence level 95\%) and ranged between $16 \%$ and $27 \%$, with an average of $21 \%$.

Modification and validation of clomazone and metazachlor method for analysis of rapeseed. A modified and validated QuEChERS method was used to analyze metazachlor and clomazone residues in rapeseed plants. The method for preparing rapeseed samples was modified versus the standardized method. The changes included reduction of the plant material weight to $5 \mathrm{~g}$, addition of $10 \mathrm{~mL}$ of water, and a changed sorbent used for clean-up, i.e., we used florisil and PSA. Florisil sorbent is not listed in the QuEChERS method, but is suitable for chlorophyll removal, while PSA is recommended for clean-up of Brassica samples ${ }^{36,37}$. To check the effectiveness of the rapeseed extracts' purification, the validation of plant samples enriched with the tested herbicidal active substances was conducted.

The fortification levels were 0.010 and $1.000 \mathrm{mg} / \mathrm{kg}$ for clomazone and 0.005 and $1.000 \mathrm{mg} / \mathrm{kg}$ for metazachlor. Recoveries were determined in five repetitions per each of the two relevant two spiking levels (Supplementary Table S2). Precision was calculated from the recovery experiments, and it was expressed as RSD at each spiking level. For both tasted sorbents, average recovery values obtained for metazachlor and clomazone in rape ranged 


\begin{tabular}{|c|c|c|c|}
\hline \multirow[b]{2}{*}{ Time (days) } & \multicolumn{3}{|c|}{ Residue level $( \pm \mathrm{RSD})(\mathrm{mg} / \mathrm{kg})$} \\
\hline & Clomazone & \multicolumn{2}{|l|}{ Metazachlor } \\
\hline \multicolumn{4}{|c|}{ Soil-field condition } \\
\hline 1 & \multicolumn{2}{|l|}{$0.758 \pm 0.025$} & $0.524 \pm 0.455$ \\
\hline 5 & \multicolumn{2}{|l|}{$0.536 \pm 0.019$} & $0.319 \pm 0.060$ \\
\hline 13 & \multicolumn{2}{|l|}{$0.380 \pm 0.054$} & $0.145 \pm 0.051$ \\
\hline 22 & \multicolumn{2}{|l|}{$0.205 \pm 0.113$} & $0.106 \pm 0.035$ \\
\hline 34 & \multicolumn{2}{|l|}{$0.062 \pm 0.034$} & $0.050 \pm 0.030$ \\
\hline \multicolumn{4}{|c|}{ Soil- laboratory condition } \\
\hline 1 & \multicolumn{2}{|l|}{$0.742 \pm 0.031$} & $0.333 \pm 0.112$ \\
\hline 5 & \multicolumn{2}{|l|}{$0.600 \pm 0.043$} & $0.221 \pm 0.007$ \\
\hline 13 & \multicolumn{2}{|l|}{$0.326 \pm 0.034$} & $0.074 \pm 0.011$ \\
\hline 22 & \multicolumn{2}{|l|}{$0.252 \pm 0.023$} & $0.059 \pm 0.006$ \\
\hline 34 & \multicolumn{2}{|l|}{$0.048 \pm 0.003$} & $<$ LOQ \\
\hline \multicolumn{4}{|c|}{ Rapeseed plant } \\
\hline 22 & $0.009 \pm 0.009$ & \multicolumn{2}{|l|}{$0.005 \pm 0.001$} \\
\hline 34 & $<$ LOQ & \multicolumn{2}{|l|}{$<$ LOQ } \\
\hline
\end{tabular}

Table 1. Average residue concentrations of clomazone and metazachlor in soil and rapeseed plants after spraying at recommended doses: clomazone $-0.2 \mathrm{~L} / \mathrm{ha}$; metazachlor $-1 \mathrm{~L} / \mathrm{h}$; $\mathrm{LOQ}$ - limit of quantification.

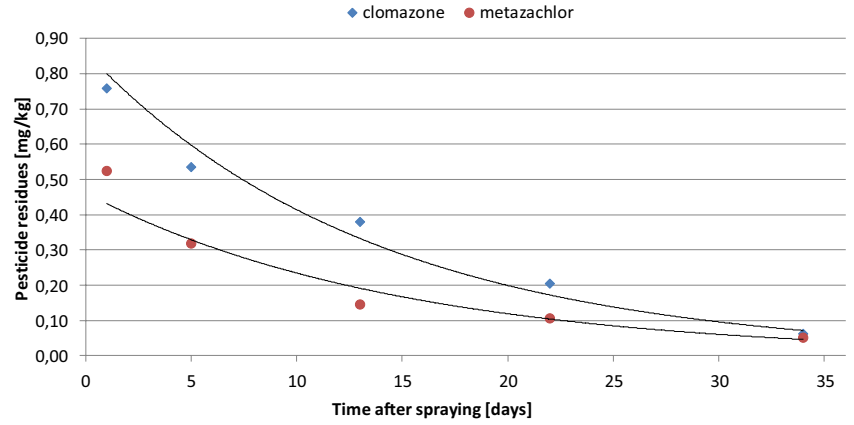

Figure 1. Dissipation of clomazone and metazachlor in the soil under field condition.

between $86 \%$ and $109 \%$, with RSD values below $12 \%$. Details are presented in Supplementary Table S2. When compared with the validation criteria for the EU method according to SANTE ${ }^{35}$, where the average recovery between 70 and $120 \%$, and RSD lower than or equal to $20 \%$ is recommended, satisfactory validation results were obtained for both analyzed substances.

To assess the selectivity of the method, chromatograms of the prepared samples cleaned with the analyzed sorbents were evaluated. Comparing both chromatograms of cleaned extracts, it can be concluded that samples cleaned with florisil contained less peaks from co-extracted substances (Supplementary Fig. S1).

Linearity was studied by analyzing matrix-matched standards in "blank" matrix at six concentration levels. The calibration curves were linear in ranges of $0.01-2.88 \mu \mathrm{g} / \mathrm{mL}$ for clomazone and $0.005-2.12 \mu \mathrm{g} / \mathrm{mL}$ for metazachlor, with coefficients of determination $\left(\mathrm{R}^{2}\right) \geq 0.99$ for both analytes (Supplementary Table S2).

The lowest spiking level corresponded to the LOQ, ensuring LOQ values corresponding to the MRLs (for Brassica plants, MRL is $0.02 \mathrm{mg} / \mathrm{kg}$ for metazachlor and $0.01 \mathrm{mg} / \mathrm{kg}$ for clomazone) ${ }^{38}$.

Method uncertainty (U) for metazachlor and clomazone was calculated following the "top-down" approach using overall recovery and precision data $^{29,39}$, reaching 6-26\% (16\% on average) for metazachlor and 7-16\% (11\% on average) for clomazone (coverage factor $\mathrm{k}=2$, confidence level of $95 \%$ ). These values are much below the limit value of $50 \%$, recommended by European Union guidelines ${ }^{35}$.

Dissipation of herbicides in soil and substance uptake by rapeseed. Samples of soils from field were collected 1, 5, 13, 22 and 34 days after herbicides application, while samples of rapeseed whole plants were collected after emergence, 22 and 34 days after herbicides application.

The laboratory tests were conducted simultaneously with the field experiment. Soil samples collected from field one day after herbicide application were stored under laboratory condition and analyzed at the same times as samples from the rapeseed field. All samples were analyzed using the validated methods described previously. The overall results of the soil and rapeseed analyses are presented in Table 1 and Figs. 1 and 2.

Table 1, Figs. 1 and 2 show the average level and the dissipation curves for clomazone and metazachlor residues in soil samples collected after 1, 5, 13, 22 and 34 days, under field and laboratory conditions, respectively. Dissipation of clomazone and metazachlor in soil under field conditions follows first-order kinetics 


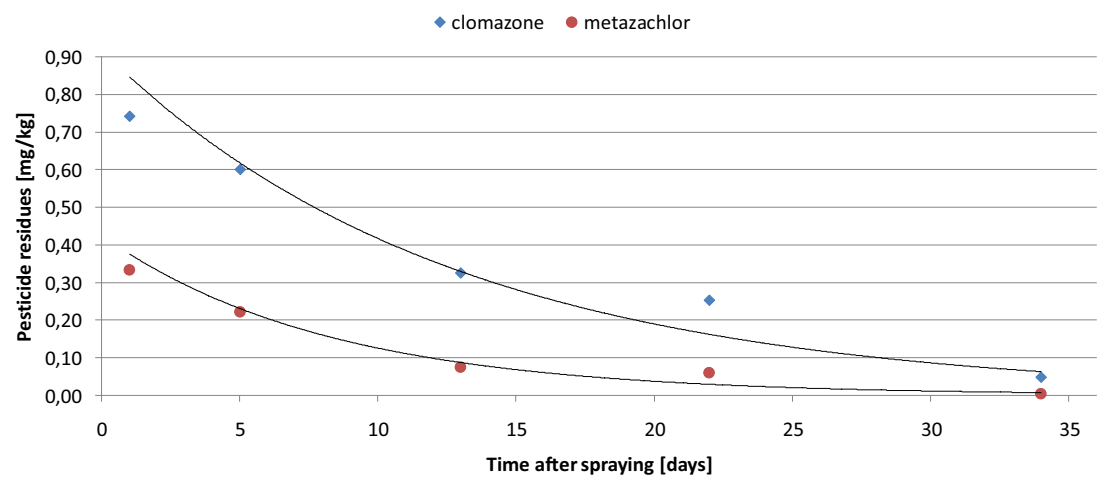

Figure 2. Dissipation of clomazone and metazachlor in the soil under laboratory condition.

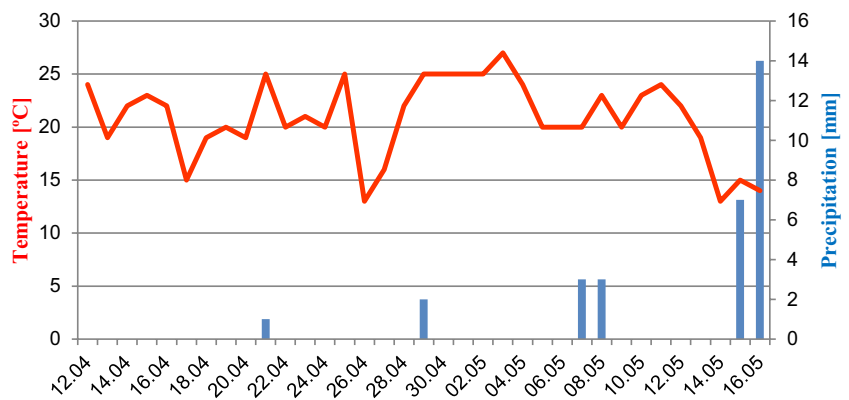

Figure 3. Weather conditions during the experiment.

$\left(\mathrm{y}=0.860 \mathrm{e}^{-0.073 \times}, \mathrm{R}^{2}=0.978\right.$ for clomazone, and $\mathrm{y}=0.461 \mathrm{e}^{-0.068 \times}, \mathrm{R}^{2}=0.964$ for metazachlor), with half-lives of 9.5 days for clomazone and 10.2 days for metazachlor. Under the laboratory conditions, dissipation of clomazone and metazachlor in soil also follows first-order kinetics $\left(y=0.915 \mathrm{e}^{-0.079 \times}, \mathrm{R}^{2}=0.938\right.$ for clomazone and $\mathrm{y}=0.424 \mathrm{e}^{-0.122 \times}, \mathrm{R}^{2}=0.937$ for metazachlor), with half-lives of 8.8 days for clomazone and 5.7 days for metazachlor.

Due to the slow growth of plants, first sampling of rapeseed for tests was possible on day 22 after the spraying. The average herbicide residue levels in these plants are shown in Table 1. 22 days after the treatment, the herbicide residue levels in rapeseed plants were below the MRL levels for Brassica plants $(<0.02 \mathrm{mg} / \mathrm{kg}$ for metazachlor, and $<0.01 \mathrm{mg} / \mathrm{kg}$ for clomazone $)^{38} .34$ days after application of herbicides, residues of these substances in rapeseed were below LOQs.

During the experiment, a small amount of precipitation, mostly at the end of experiment, was recorded (30 $\mathrm{mm}$ in total during 34 days of tests) (Fig. 3).

Confirmation of the obtained results by gas chromatography with mass spectrometry. The results obtained in field experiments were confirmed qualitatively by gas chromatography combined with mass spectrometry (GC/MS/MS). Examples of spectra for the tested compounds, rapeseed and soil samples are included in the Supplementary Fig. S2 and Fig. S3.

\section{Discussion}

The aim of this study was to analyze dissipation of metazachlor and clomazone, herbicides widely used in rapeseed (Brassica napus L. subsp. napus) protection, applied to the soil under field and laboratory conditions. Furthermore, the uptake of these pesticides from soil by rapeseed plants was investigated under field conditions. An additional aim of this work was to modify the QuEChERS method for the determination of metazachlor and clomazone in the plant material, and validation of the method for the analyses of these substances in the soil.

In the literature, the availability of information about the dissipation of these two herbicides in soil is limited and the information about uptake of herbicide residues by rapeseed plants is scarce; therefore, these studies can be considered as a novel approach.

Before starting our research on herbicide dissipation, we validated the method for determination of these herbicides in soil, and modified and validated the QuEChERS method for herbicide determination in rapeseed. The values of characteristic parameters obtained in the validation process confirmed that the methods meet the requirements of the European Commission and are suitable for the determination of pesticide residues in soil, rapeseed, and plants with a high chlorophyll content.

Other authors used high performance liquid chromatography (HPLC) with diode array detection (DAD) for determination of clomazone in soybeans; the calculated limit of quantification for this method was $0.05 \mathrm{mg} / \mathrm{kg}^{40}$. Also in other studies in soybeans, the same technique was used using florisil as a sorbent for cleanup. In this case, 
the limit of quantification was $0.01 \mathrm{mg} / \mathrm{kg}^{41}$. Metazachlor was determined in oilseed rape using the reverse-phase HPLC (RP - HPLC) with UV - VIS detection, where the limit of quantification was $0.8 \mathrm{mg} / \mathrm{mL}^{42}$. In other studies, HPLC with DAD detection ${ }^{41}$, HPLC with UV detection, and gas chromatography with ECD detection were used to determine clomazone in soil ${ }^{43}$. For the determination of metazachlor in soil, gas chromatography with mass spectrometry was used, with sorbents: PSA, C18, GCB, $\mathrm{MgSO}_{4}$ (PSA and C18), which selectively adsorb interferences from soil, such as organic matter or humic acid (GCB adsorbs pigments and $\mathrm{MgSO}_{4}$ adsorbs water from the extract). In this case, the limit of quantification was $0.01 \mathrm{mg} / \mathrm{kg}^{44}$.

The aim of this study was to analyze the behavior of clomazone and metazachlor residues in soil and in rapeseed plants. Other studies showed relatively rapid dissipation of herbicides used on weeds, mainly during their germination. After application of these agents, the weeds do not grow, or after the emergence, they became white and dry out.

According to other authors, the half-life of clomazone in the soil was 7.48 days ${ }^{41}$ or 6-59 days ${ }^{45}$. Quayle et al. ${ }^{46}$ also determined the degradation time of this herbicide in soil, and it was found to be $t_{1 / 2}=14$. 6 days, while the maximum concentration of clomazone in the soil was $202 \mu \mathrm{g} / \mathrm{L}$, therefore, after 18.4 days the compound was degraded to the levels appropriate for preservation of aquatic ecosystems. According to the Pesticide Properties Data Base (PPDB), atypical value of $t_{1 / 2}$ for clomazone in field soil is equal to 22.6 days, but according to the EU dossier, this herbicide half-life in soil ranges between 6.3 and 145.7 days (lab studies), and 9.3 and 195 days (field

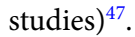

On a basis of dissipation results for metazachlor in soil ${ }^{48}$, it can be stated that its half-life ranges between 10.92 and 12.68 days, and this herbicide was detected in the soil even 170 days after spraying. Levels of metazachlor residues in the soil were also calculated for the years $2003-2005$ by Kucharski and Badowski ${ }^{43}$. The obtained values were within range of $<0.001-0.021 \mathrm{mg} / \mathrm{kg}$. Taking into account the results from the whole research period, at the time of crop harvesting the residues of the tested herbicide were detected in $80 \%$ of soil samples ${ }^{43}$. According to PPDB for soil in field conditions, a typical value of $t_{1 / 2}$ for metazachlor in soil is equal to 8.6 days, but according to the EU dossier, half-lives for this herbicide in soil range from 5.5 to 25.3 days (lab studies) and 2.8 to 21.3 days (field studies) ${ }^{47}$.

The results of our study indicate that temperature can influence dissipation of clomazone and metazachlor in soil. In the laboratory conditions clomazone and metazachlor half-lives were shortened by 0.7 days and 4.5 day, respectively, in comparison to the field values. The average temperature was $20.8^{\circ} \mathrm{C}$ (ranging from 13 to $27^{\circ} \mathrm{C}$ ) in the field and was maintained at $22^{\circ} \mathrm{C} \pm 1{ }^{\circ} \mathrm{C}$ in the laboratory conditions. The higher and stable temperature, together with the more stable moisture content of soil in the laboratory $(36 \pm 2 \%)$ than in the field $(35 \pm 10 \%)$ could lead to a more effective biodegradation process. Generally, as the temperature and humidity increase, the microbial degradation process accelerates. Periods of drought or low temperatures inhibit the growth of microorganisms, resulting in slowing down the decomposition of herbicides ${ }^{11}$.

According to other authors, microbial metabolisms of clomazone and metazachlor form a major degradation pathway ${ }^{49,50}$. The rate of clomazone degradation is affected by soil moisture, temperature, microorganisms, $\mathrm{pH}$, and is accelerated under anaerobic conditions ${ }^{51}$. The degradation of metazachlor may be affected by soil type, soil texture fraction, organic carbon content, and $\mathrm{pH}$, and is faster under anaerobic conditions ${ }^{52,53}$.

In the present research, the levels of herbicide residues in rapeseed plants were calculated. The herbicide residues in rapeseed plants 22 days after the treatment were below the MRLs for Brassica plants $(<0.01 \mathrm{mg} / \mathrm{kg}$ for clomazone $)^{38}$. The literature does not contain any data on the clomazone residues uptake by rapeseed. However, clomazone residues at a level of $<0.01 \mathrm{mg} / \mathrm{kg}$ were found in soybeans ${ }^{41}$. Similar results on the clomazone dissipation, of $t_{1 / 2}$ of 4.9 days and residue levels ranging between 0.0037 and $0.033 \mathrm{mg} / \mathrm{kg}$, were obtained in studies on soybean plants ${ }^{40}$.

In the experiments concerning metazachlor conducted by Koleva-Valkova et al. ${ }^{42}$ on rapeseed leaves, the active substance was applied in two ways, into soil and foliarly. In the first case, the highest concentration $(14.6 \mathrm{mg} / \mathrm{kg})$ was recorded in the leaves 28 days after herbicide treatment. The concentration level was $4.4 \mathrm{mg} /$ $\mathrm{kg}$ and $1.23 \mathrm{mg} / \mathrm{kg}$ after 48 and 68 days, respectively. Following the foliar application, the metazachlor residue was determined after 8 and 20 days and amounted to $4.24 \mathrm{mg} / \mathrm{kg}$ and $0.95 \mathrm{mg} / \mathrm{kg}$, respectively. Kucharski and Badowski ${ }^{43}$ analyzed metazachlor uptake by white mustard (Sinapis alba). The maximum value of this herbicide in seeds was $0.009 \mathrm{mg} / \mathrm{kg}$ which was below MRL.

Many scientists concluded that in addition to the environmental conditions, the applied concentration and type of pesticide formulation, the physical and living state of the plant surface, the relation between the treated surface and plant weight, are the most effective factors acting on the initial deposits of the pesticides ${ }^{54,55}$.

\section{Conclusions}

The modified QuEChERS-method with extracts cleanup using florisil or PSA followed by the analysis by $\mathrm{GC}-\mu \mathrm{ECD}$, could be used with satisfying results for quantification of clomazone and metazachlor in rapeseed plants, and this method met the criteria for methods for determining pesticide residues.

The higher and stable temperature, together with the stable moisture content of soil in the laboratory could lead to more efficient biodegradation of tested herbicides.

Application of clomazone and metazachlor directly after rapeseed sowing results in a very low uptake of these substances by plants.

\section{Materials and Methods}

Soil properties. Soil characteristics (soil type, granulometric composition, $\mathrm{pH}$, assimilable phosphorus, total carbon, organic carbon, humus content, total nitrogen, phosphorus, magnesium, potassium and calcium) were determined in laboratory of The Institute of Soil Science and Plant Cultivation in (Pulawy, Poland) accredited by The Polish Centre for Accreditation (certificate no AB 339). 
Metazachlor and clomazone analysis in soil. Analytical portions of $20 \mathrm{~g}$ were taken from the soil samples (weight of each sample $>200 \mathrm{~g}$ ) ${ }^{56}$, and weighted in a $250 \mathrm{~mL}$ Erlenmeyer flask. $50 \mathrm{~mL}$ of dichloromethane (Sigma-Aldrich Sp. z o.o., Poland) and acetone (Chempur, Poland) mixture (9:1; v/v) were added and shaken for $1 \mathrm{~h}$ on a GFL 3006 shaker (Germany). The extracts were allowed to stand for $10 \mathrm{~min}$ and then decanted through a layer of anhydrous sodium sulfate(VI) $\mathrm{Na}_{2} \mathrm{SO}_{4}$ (POCH, Poland) placed in a funnel. The soil samples were washed twice with $20 \mathrm{~mL}$ of dichloromethane, and the combined extracts were evaporated to dryness on a rotary evaporator (Heidolph Laborota 4000 Efficient, Germany) at temperature below $40^{\circ} \mathrm{C}$. The residues were then dissolved in $10 \mathrm{~mL}$ of petroleum ether (Chempur, Poland) $)^{57}$.

Metazachlor and clomazone analysis in rapeseed. For the determination of clomazone and metazachlor in the plant material of a high chlorophyll content (rapeseed), the standardized method: PN-EN 15662:2018 "Foods of plant origin-Multimethod for the determination of pesticide residues using GC- and LC-based analysis following acetonitrile extraction/partitioning and clean-up by dispersive SPE-Modular QuEChERS-method" was modified ${ }^{37}$. The abovementioned standard does not provide guidelines for rapeseed plants regarding the amount of sample to be analyzed, the addition of water before extraction, and sorbents used for the purification of extracts. The detection technique was changed from GC-MS in the normalized method to GC- $\mu$ ECD.

The analytical sample of the plant material was ground in a homogenizer (Waring Commercial 8010 EG blender, USA) and mixed thoroughly, not allowing separation of the juice from the solids. An analytical portion of $5 \mathrm{~g}$ was taken and placed in a $50 \mathrm{~mL}$ centrifuge tube, then $5 \mathrm{~mL}$ of distilled water and $10 \mathrm{~mL}$ of acetonitrile (Chempur, Poland) were added. The contents of the tube were shaken for $1 \mathrm{~min}$. Next, a mixture of buffer salts: $4 \mathrm{~g}$ $\mathrm{MgSO}_{4}$ (Chempur, Poland), $1 \mathrm{~g} \mathrm{NaCl}$ (Chempur, Poland), $0.5 \mathrm{~g}$ hydrated disodium hydrogen citrate (Chempur, Poland), an $1 \mathrm{~g}$ hydrated trisodium citrate (Chempur, Poland), was added, and the sample was shaken again for $1 \mathrm{~min}$, and centrifuged at $>3000 \mathrm{rpm}$ (MPW-350R, MPW MED. INSTRUMENTS, Warsaw, Poland) for $5 \mathrm{~min}$. $6 \mathrm{~mL}$ of the acetonitrile layer was transferred to a $15 \mathrm{~mL}$ propylene tube containing sorbent for clean-up extracts:

(i) $150 \mathrm{mg}$ Primary Secondary Amine (PSA Agilent, USA), and $900 \mathrm{mg} \mathrm{MgSO}_{4}$,

(ii) $1 \mathrm{~g}$ of florisil (Sigma-Aldrich Sp. z o.o., Poland) and $900 \mathrm{mg}$ of $\mathrm{MgSO}_{4}$

Once again, the rapeseed was shaken vigorously for $1 \mathrm{~min}$ and then centrifuged at $>3000 \mathrm{rpm}$ (MPW-350R, MPW MED. INSTRUMENTS, Warsaw, Poland) for $5 \mathrm{~min}$. $1 \mathrm{~mL}$ of extract was transferred to a $2 \mathrm{~mL}$ chromatographic glass vial. Acetonitrile was evaporated under a nitrogen stream and then $1 \mathrm{~mL}$ of petroleum ether (Chempur, Poland) was added.

Pesticide analytical standards. Certified analytical standards of metazachlor and clomazone were purchased from Ehrenstorfer (Germany). Stock solutions of approximately $1000 \mu \mathrm{g} / \mathrm{mL}$ were prepared in acetone and stored at $-16^{\circ} \mathrm{C}$, and were used to prepare intermediate concentration standards by dilution with acetone (stored at $4^{\circ} \mathrm{C}$ ). Working standard mixtures were obtained by diluting the intermediate concentration solutions with appropriate volumes of petroleum ether (stored at $4^{\circ} \mathrm{C}$ ).

Chromatographic and mass spectrometry analysis. A 7890 A gas chromatograph (Agilent Technologies, Palo Alto, CA, USA) with a micro electron capture detector (GC- $\mu$ ECD) was used to qualify and quantify herbicide residues in soil and rapeseed samples. A mass detector equipped with three quadrupoles, model 7000 (GC-MS/MS QqQ) was used to confirm metazachlor and clomazone residues in plant and soil material. Details of chromatographic parameters are provided in Supplementary Tables S3 and S4.

In the MRM mode, multiple reactions can be monitored and selected fragmentation reactions can be observed, allowing recording the presence of relevant compounds ${ }^{58}$.

Clomazone and metazachlor spectra were recorded in the full scan mode and then characteristic ion fragments were selected. In the MRM mode, the following transitions were selected: $125.0 \rightarrow 121.7$ and $89.3(\mathrm{~m} / \mathrm{z})$ for clomazone, and $209.1 \rightarrow 132.1$ and $132.1 \rightarrow 117.3(\mathrm{~m} / \mathrm{z})$ for metazachlor.

Validation study. The validation was performed using the following parameters: trueness and precision (expressed as an average recovery and a relative standard deviation, RSD), linearity (expressed as a coefficient of determination $\mathrm{R}^{2}$ ), LOQs, and uncertainty according to the European Union guideline SANTE ${ }^{35}$.

The material for validation study was soil and rapeseed plants without pesticide residues. Recovery studies were used to calculate the trueness and precision of the methods. Before the analysis, samples were enriched with the standards of the pesticides active substances, at two levels: of $1 \mathrm{mg} / \mathrm{kg}$ (for both substances) and of $0.01 \mathrm{mg} / \mathrm{kg}$ for clomazone and $0.005 \mathrm{mg} / \mathrm{kg}$ for metazachlor. The samples were analyzed in five replicates $(\mathrm{n}=5)$.

The LOQ for each pesticide was defined as the lowest spiking level meeting the recovery requirement and RSD for different fortification levels.

Linearity was evaluated using six-point matrix-matched standards (in "blank" matrix), of concentrations ranging $0.01-2.88 \mu \mathrm{g} / \mathrm{mL}$ and $0.005-2.12 \mu \mathrm{g} / \mathrm{mL}$ for clomazone and metazachlor, respectively.

Expanded measurement uncertainties were estimated using a "top-down" empirical model according to the

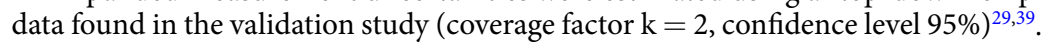

Dissipation of herbicides in soil and rapeseed. Metax 500 SC (INNVIGO Sp. z o.o., Poland) is a preparation that combats mono-and dicotyledonous annual weeds. It is recommended in the cultivation of rapeseed and white headed cabbage. The active substance of this preparation is metazachlor $(500 \mathrm{~g}$ of metazachlor per $1 \mathrm{~L}$ of the plant protection product ${ }^{59}$. According to the International Union of Pure and Applied Chemistry (IUPAC) nomenclature, metazachlor is called 2-chloro-2', 6' -dimethyl-N-(1H-pyrazol-1-ylmethyl)acetanilide (Fig. 4). 
<smiles>CC1(C)CON(Cc2ccccc2Cl)C1=O</smiles>

Clomazone<smiles>Cc1cccc(C)c1N(Cn1cccn1)C(=O)CCl</smiles>

Metazachlor

Figure 4. Molecular structures of herbicides.

Command 480 EC (FMC Chemical s.p.r.l., Belgium) is preparation intended for combating some annual dicots and monocots in beans, peas, carrots, cucumbers, rapeseed and potatoes. The active substance of this preparation is clomazone ( $480 \mathrm{~g}$ of clomazone per $1 \mathrm{~L}$ of the plant protection product) ${ }^{59}$. According to IUPAC nomenclature, clomazone is called 2-(2-chlorobenzyl)-4, 4-dimethylisoxazolidin-3-one (Fig. 4).

The trial was conducted in an agricultural farm that implements principles of integrated production. The farm was located in Budziwój (south-eastern Poland, an administrative division of Podkarpackie Voivodeship).

On 12 April 2018, rape seeds were sown in a field of an area of 2 ha. Herbicides: Command 480 EC at a recommended dose of $0.2 \mathrm{~L} / \mathrm{ha}$, and Metax $500 \mathrm{SC}$ at a dose of $1 \mathrm{~L} /$ ha were applied on 13 April 2018 on the whole cultivated field. The samples of soil and rapeseed were collected according to provisions of the national regulation ${ }^{56}$. The soil samples of $200 \mathrm{~g}$ were collected on five dates: $1,5,13,22$, and 34 days after herbicide application, with Egner's stick (at $0-20 \mathrm{~cm}$ depth) following a W-shaped path across the field, in four replicates $(\mathrm{n}=4)$. The plant material samples of $200 \mathrm{~g}$ were collected after plant emergence (on two dates), in four replicates. The rapeseed plants were very small and were analyzed as a whole. The plant material was ground in a homogenizer (Waring Commercial 8010 EG blender, USA) and mixed thoroughly, to prevent juice separation from solids. An analytical portion of $5 \mathrm{~g}$ was taken for herbicide analysis.

The weather conditions (the average daily temperature and precipitation) were monitored throughout the experiment ${ }^{60}$ (Fig. 3).

The laboratory test was conducted simultaneously with the field experiment. $400 \mathrm{~g}$ of soil, collected from field one day after herbicide application, were weighted into a $2 \mathrm{~L}$ transparent propylene container, in four replicates. Samples were stored in monitored conditions, at $22^{\circ} \mathrm{C} \pm 1^{\circ} \mathrm{C}$. Samples for pesticide analysis were taken $1,5,13$, 22 and 34 days after treatment - on the same dates as samples from the rapeseed field. Before sampling, each soil was thoroughly mixed with a laboratory spoon.

In each soil sample, water content was measured by the weighing method after drying at $105^{\circ} \mathrm{C} \pm 3^{\circ} \mathrm{C}(\mathrm{S}-40$, Alpina, Poland $)^{61}$. The pesticide concentration was calculated for soil dry mass.

The dissipation kinetics of metazachlor and clomazone residues were determined by plotting the concentration against the time elapsed after treatment. It was found that they followed the exponential relationship with time, corresponding to the first-order kinetics Eq. 1:

$$
\mathrm{y}=\mathrm{y}_{\mathrm{o}} \mathrm{e}^{-\mathrm{kx}}
$$

where: $\mathrm{y}$ - concentration of the herbicide residue at a given time, $\mathrm{y}_{\mathrm{o}}$ - initial herbicide concentration, $\mathrm{k}$ - constant rate of herbicide dissipation per day.

On the basis of this equation, the dissipation half-life periods $\left(t_{1 / 2}=\ln (2) / k\right)$ were calculated for the tested herbicides ${ }^{62}$.

Received: 30 September 2019; Accepted: 16 February 2020;

Published online: 28 February 2020

\section{References}

1. Popp, J., Pető, K. \& Nagy, J. Pesticide productivity and food security. A review. Agron. Sustain. Dev. 33(1), $243-255$ (2013).

2. Mansilha, C. et al. Quantification of endocrine disruptors and pesticides in water by gas chromatography-tandem mass spectrometry. Method. Valid. using. weighted linear Regres. schemes. J. Chromatogr. A 1217, 6681-6691 (2010).

3. Kim, K.-H., Kabirb, E. \& Jahan, S. A. Exposure to pesticides and the associated human health effects. Review. Sci. Total. Environ. 575, 525-535 (2017)

4. Silva, V. et al. Pesticide residues in European agricultural soils - A hidden reality unfolded. Sci. Total. Environ. 653(25), 1532-1545 (2019).

5. Codex Alimentarius, International Food Standards, www.fao.org/fao-who-codexalimentarius/en/ (2019).

6. Environmental Protection Agency, www.epa.gov/pesticide-tolerances (2019).

7. Regulation (EC) No 396/2005 of the European Parliament and of the Council of 23 February 2005 on maximum residue levels of pesticides in or on food and feed of plant and animal origin and amending Council Directive 91/414/EEC. Off. J. L 70, with later amendments, https://eur-lex.europa.eu/legal-content/EN/TXT/PDF/?uri=CELEX:32005R0396\&from=EN (2019).

8. Regulation 149/2008. COMMISSION REGULATION (EC) No 149/2008 of 29 January 2008 amending Regulation (EC) No $396 / 2005$ of the European Parliament and of the Council by establishing Annexes II, III and IV setting maximum residue levels for products covered by Annex I thereto. Off. J. L 58, https://eur-lex.europa.eu/legal-content/EN/TXT/PDF/?uri=CELEX:32008R0149\&from=en (2019).

9. Schoonover, J. E. \& Crim, J. F. An Introduction to Soil Concepts and the Role of Soils in Watershed Management. J. Contemp. Water Res. Educ. 154, 21-47 (2015). 
10. Fernandes, V. C., Domingues, V. F., Mateus, N. \& Delerue-Matos, C. Multiresidue pesticides analysis in soils using modified QuEChERS with disposable pipette extraction and dispersive solid-phase extraction. J. Sep. Sci. 36, 376-382 (2013).

11. Grygiel, K., Sadowski, J., Snopczyński, T. \& Wysocki, A. Herbicide residues in agricultural products and in the soil. J.Ecol.Health 16(4), 159-163 (2012).

12. Andrea, M. M. et al. Influence of repeated applications of glyphosate on its persistence and soil bioactivity. Pesq. Agropec. Bras. 38(11), 1329-1335 (2003).

13. Yang, X. -B., Ying, G. -G. \& Kookana, R. S. Rapid multiresidue determination for currently used pesticides in agricultural drainage waters and soils using gas chromatography-mass spectrometry. J. Environ. Sci. Health. Part. B 45, 152-161 (2010).

14. Sanghi, R. \& Kannamkumarath, S. S. Comparison of extraction methods by soxhlet, sonicator, and microwave in the screening of pesticide residues from solid matrices. J. Anal. Chem. 59(11), 1032-1036 (2004).

15. Wang, W., Meng, B., Lu, X., Liu, Y. \& Ta, S. Extraction of polycyclic aromatic hydrocarbons and organochlorine pesticides from soils: A comparison between Soxhlet extraction, microwave-assisted extraction and accelerated solvent extraction techniques. Anal. Chim. Acta 602(2), 211-222 (2007).

16. Rao, M. M., Kumar Meena, A. \& Galib, E. Detection of toxic heavy metals and pesticide residue in herbal plants which are commonly used in the herbal formulations. Environ. Monit. Assess. 181, 267-271 (2011).

17. Tong, H., Tong, Y., Xue, J., Liu, D. \& Wu, X. Multi-residual pesticide monitoring in commercial Chinese herbal medicines by gas chromatography-triple quadrupole tandem mass spectrometry. Food Anal. Methods 7, 135-145 (2014).

18. Dąbrowska, H., Dąbrowski, L., Biziuk, M., Gaca, J. \& Namieśnik, J. Solid-phase extraction clean-up of soil and sediment extracts for the determination of various types of pollutants in a single run. J. Chromatogr. A 1003(1-2), 29-42 (2003).

19. Masiá, A., Vásquez, K., Campo, J. \& Picó, Y. Assessment of two extraction methods to determine pesticides in soils, sediments and sludges. Application to the Túria River Basin. J. Chromatogr. A 1378, 19-31 (2015).

20. Homazava, N., Aquillon, C. G., Vermeirssen, E. \& Werner, I. Simultaneous multi-residue pesticide analysis in soil samples with ultra-high-performance liquid chromatography-tandem mass spectrometry using QuEChERS and pressurised liquid extraction methods. Int. J. Env. Anal. Chem. 94(11), 1085-1099 (2014).

21. Carpinteiro, I., Casado, J., Rodriguez, I., Ramil, M. \& Cela, R. Optimization of matrix solid-phase dispersion conditions for organic fungicides determination in soil samples. J. Sep. Sci. 35(7), 853-860 (2012).

22. Lozowicka, B. et al. The evaluation of a fast and simple pesticide multiresidue method in various herbs by gas chromatography. J. Nat. Med. 68(1), 95-111 (2014).

23. Sarkhail, P., Yunesian, M., Ahmadkhaniha R., Sarkheil, P. \& Rastkari, N. Levels of organophosphorus pesticides in medicinal plants commonly consumed in Iran. Daru J. Pharm. Sci. 20(1), 9, https://link.springer.com/content/pdf/10.1186\%2F2008-2231-20-9.pdf (2012).

24. Fernandez-Alvarez, M. et al. Simultaneous determination of traces of pyrethroids, organochlorines and other main plant protection agents in agricultural soils by headspace solid-phase microextraction-gas chromatography. J. Chromatogr. A 1188, 154-163 (2008).

25. Pastor-Belda, M. et al. Dispersive liquid-liquid microextraction for the determination of new generation pesticides in soils by liquid chromatography and tandem mass spectrometry. J. Chromatogr. A 1394, 1-8 (2015).

26. Anastassiades, M., Lehotay, S. J., Stajnbaher, D. \& Schenck, F. J. Fast and easy multiresidue method employing acetonitrile extraction/ partitioning and "dispersive solid-phase extraction" for the determination of pesticide residues in produce. J. AOAC Int. 86(2), 412-431 (2003).

27. Correia-Sá, L. et al. Optimization of QuEChERS method for the analysis of organochlorine pesticides in soils with diverse organic matter. J. Sep. Sci. 35, 1521-1530 (2012).

28. Pinto, C. G. et al. Simplified QuEChERS approach for the extraction of chlorinated compounds from soil samples. Talanta 81(1-2), 385-391 (2010).

29. Słowik-Borowiec, M., Szpyrka, E. \& Walorczyk, S. Gas chromatographic determination of pesticide residues in white mustard. Food Chem. 173, 997-1005 (2015).

30. Rutkowska, E., Łozowicka, B. \& Kaczyński, P. Modification of Multiresidue QuEChERS Protocol to minimize matrix effect and improve recoveries for determination of pesticide residues in dried herbs followed by GC-MS/MS. Food Anal. Methods 11(3), 709-724 (2018)

31. Jiang, Y., Li, Y., Jiang, Y., Li, J. \& Pan, C. Determination of multiresidues in rapeseed, rapeseed oil, and rapeseed meal by acetonitrile extraction, low-temperature cleanup, and detection by liquid chromatography with tandem mass spectrometry. J. Agric. Food Chem. 60(20), 5089-5098 (2012)

32. Mikhail, F. Z., Leschev, S. M. \& Zayats, M. A. An improved extraction method of rapeseed oil sample preparation for the subsequent determination in it of azole class fungicides by gas chromatography. Anal. Chem. Res. 3, 37-45 (2015).

33. Remlein-Starosta, D., Drożdżyński, D. \& Kowalska, J. Occurrence of fungal and pesticides contamination in rapeseeds depending on the cultivars and systems of farming. Plant. Soil. Environ. 61(2), 49-54 (2015).

34. Dauguet, S. Insecticide residues cross-contamination of oilseeds during storage. OCL - Oilseeds Fats, Crop. Lipids 14(6), 313-316 (2009).

35. European Commission Directorate General for Health and Food Safety SANTE/11813/2017. Guidance document on analytical quality control and method validation procedures for pesticide residues and analysis in food and feed, www.ec.europa.eu/food/sites/ food/files/plant/docs/pesticides_mrl_guidelines_wrkdoc_2017-11813.pdf (2019).

36. Sadowska-Rociek, A. \& Cieślik, E. The techniques used and the latest trends in the determination of pesticide residues in food by gas chromatography. Chem. Dydaktyka Ekologia Metrologia 13,33-38 (2008).

37. PN-EN 15662:2018 Foods of plant origin-Multimethod for the determination of pesticide residues using GC- and LC-based analysis following acetonitrile extraction/partitioning and clean-up by dispersive SPE-Modular QuEChERS-method. The Polish Committee for Standardization, Warsaw, Poland, 1-82 (2018).

38. EU Pesticide database, www.ec.europa.eu/food/plant/pesticides/eu-pesticides-database/public/?event=homepage\&language $=\mathrm{EN}$ (2019).

39. Medina-Pastor, P. et al. Comparative study of the main top-down approaches for the estimation of measurement uncertainty in multiresidue analysis of pesticides in fruits and vegetables. J. Agric. Food Chem. 59(14), 7609-7619 (2011).

40. Nalini, R. R. P., Janaki, P., Balusamy, M. \& Chinnusamy, C. Persistence and residua of Clomazone in soil and soybean by HPLCDAD. Asian J. Chem. 28(1), 51-54 (2015).

41. Hu, J., Cao, D. \& Deng, Z. Determination of clomazone residues in soybean and soil high performance liquid chromatography with DAD detection. Bull. Env. Contam. Toxicol. 86(4), 444-448 (2011).

42. Koleva-Valkova, L., Vasilev, A., Dimitrova, M. \& Stoychev, D. Determination of metazachlor residues in winter oilseed rape (Brassica Napus Var. Xenon) by HPLC. Emir. J. Food Agric. 28(11), 813-817 (2016).

43. Kucharski, M. \& Badowski, M. Pozostałości herbicydów w glebie i nasionach gorczycy białej. Rośliny Oleiste - Oilseed Crop. 27, $89-93$ (2006).

44. Wenquan, M., Qiwan, L., Haixian, F., Huichun, G. \& Xinglian, C. Determination of six amide herbicide residues in soil by QuEChERS-gas chromatography-mass spectrometry. Se Pu 35(12), 1317-1321 (2017)

45. Cumming, J. P., Doyle, R. B. \& Brown, P. H. Clomazone dissipation in four Tasmanian topsoils. Weed Sci. 50(3), 405-409 (2002).

46. Quayle, W. C., Oliver, D. P. \& Zrna, S. Field dissipation and environmental hazard assessment of clomazone, molinate, and thiobencarb in Australian rice culture. J. Agric. Food Chem. 54(19), 7213-7220, https://doi.org/10.1021/jf061107u (2006). 
47. PPDB database, https://sitem.herts.ac.uk/aeru/ppdb/en/ (2019).

48. Mantzos, N., Hela, D., Karakitsou, A., Antonopoulou, M. \& Konstantinou, I. Dissipation and runoff transport of metazachlor herbicide in rapeseed cultivated and uncultivated plots in field conditions. Environ. Sci. Pollut. Res. Int. 23(20), 20517-20527 (2016).

49. Van Scoy, A. R. \& Tjeerdema, R. S. Environmental Fate and Toxicology of Clomazone. Rev. Environ. Contam. Toxicol. 229, 35-49 (2014).

50. Mamy, L., Barriuso, E. \& Gabrielle, B. Environmental fate of herbicides trifluralin, metazachlor, metamitron and sulcotrione compared with that of glyphosate, a substitute broad spectrum herbicide for different glyphosate-resistant crops. Pest. Manag. Sci. 61(9), 905-16 (2005).

51. Cao, J., Diao, X.-P. \& Hu, J.-Y. Hydrolysis and Photolysis of Herbicide Clomazone in Aqueous Solutions and Natural Water Under Abiotic Conditions. J. Integr. Agric. 12(11), 2074-2082 (2013).

52. Sadowski, J., Kucharski, M. \& Wujek, B. Influence of soil type on metazachlor decay. Prog. Plant. Prot. 52(2), 437-440 (2012).

53. EFSA (European Food Safety Authority), Conclusion on the peer review of the pesticide risk assessment for the active substance metazachlor in light of confirmatory data submitted. EFSA Journal 15(6), 4833, 1-48 (2017).

54. Almaz, M. M. Residues of some pesticides on some plants of medical importance, $\mathrm{PhD}$ thesis, Faculty of Agriculture, Moshtohor Zagazig University, Egypt (1985).

55. Khay, S. et al. Dissipation behavior of lufenuron, benzoyphenylurea insecticide, in/on Chines cabbage applied by foliar spraying under greenhouse condition. Bull. Environ. Contam. Toxicol. 81, 369-72 (2008).

56. Rozporządzenie Ministra Rolnictwa i Rozwoju Wsi z dnia 27 listopada 2013 r. w sprawie pobierania próbek roślin, produktów roślinnych lub przedmiotów do badań na obecność pozostałości środków ochrony roślin DZ.U. z 2013 r. Nr 00, poz. 1549, http:// extwprlegs1.fao.org/docs/pdf/pol129665.pdf (2019).

57. Sadło, S., Szpyrka, E., Stawarczyk, M. \& Piechowicz, B. Behavior of pyrimethanil, pyraclostrobin, boscalid, cypermethrin and chlorpyrifos residues on raspberry fruit and leaves of Laszka variety. J. Environ. Sci. Health Part. B 49(3), 159-168 (2014).

58. Stolarczyk, E. \& Kutner, A. Zastosowanie spektrometrii mas w analizie farmaceutycznej zanieczyszczeń organicznych. Farm. Pol. 65(8), 586-593 (2009).

59. Labels-instructions for use on plant protection products approved for marketing and application with a permit of the Ministry of Agriculture and Rural Development, www.gov.pl/web/rolnictwo/etykiety-srodkow-ochrony-roslin (2019).

60. Meteorological data, www.ekologia.pl/pogoda/polska/podkarpackie/rzeszow/archiwum,zakres,12-04-2018_12-05-2018,calosc (2018).

61. PN-ISO 11465:1999. Soil quality - Determination of dry matter content of soil and water in soil calculated on the dry mass of soil Weight method. The Polish Committee for Standardization, Warsaw, Poland, 1-7 (1999).

62. Szpyrka, E., Matyaszek, A. \& Słowik-Borowiec, M. Dissipation of chlorantraniliprole, chlorpyrifos-methyl and indoxacarbinsecticides used to control codling moth (Cydia Pomonella L.) and leafrollers (Tortricidae) in apples for production of baby food. Environ. Sci. Pollut. Res. Int. 24(13), 12128-12135 (2017).

\section{Acknowledgements}

We would like to thank Dr. hab. Grzegorz Siebielec for the analysis of soil properties. This research was funded by the Ministry of Science and Higher Education [Grant Number WB/PB/VIII/2018 "Presence and disappearance of pesticide active substances in plant material and environmental samples"].

Author contributions

E.S. designed the research; E.S., M.P., P.K. and A.Z. performed experiments; E.S., P.K. and M.S.B. wrote the manuscript.

\section{Competing interests}

The authors declare no competing interests.

\section{Additional information}

Supplementary information is available for this paper at https://doi.org/10.1038/s41598-020-60720-0.

Correspondence and requests for materials should be addressed to E.S.

Reprints and permissions information is available at www.nature.com/reprints.

Publisher's note Springer Nature remains neutral with regard to jurisdictional claims in published maps and institutional affiliations.

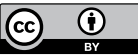

Open Access This article is licensed under a Creative Commons Attribution 4.0 International License, which permits use, sharing, adaptation, distribution and reproduction in any medium or format, as long as you give appropriate credit to the original author(s) and the source, provide a link to the Creative Commons license, and indicate if changes were made. The images or other third party material in this article are included in the article's Creative Commons license, unless indicated otherwise in a credit line to the material. If material is not included in the article's Creative Commons license and your intended use is not permitted by statutory regulation or exceeds the permitted use, you will need to obtain permission directly from the copyright holder. To view a copy of this license, visit http://creativecommons.org/licenses/by/4.0/.

(C) The Author(s) 2020 